\title{
PENGARUH DISPLIN KERJA DAN KEPUASAN KERJA TERHADAP KINERJA PEGAWAI DENGAN TAMBAHAN PENGHASILAN PEGAWAI SEBAGAI VARIABEL MODERATING
}

Agustina Widia; Endang Rusdianti

agustinawidya30@gmail.com; endang_rus@usm.ac.id

Magister Manajemen, Universitas Semarang, Semarang Indonesia

\section{Info Artikel}

Sejarah Artikel :

Diterima

Disetujui

Dipublikasi

Kata Kunci :

Displin Kerja,

Kepuasan Kerja,

Kinerja Pegawai,

Tambahan

Penghasilan Pegawai

\section{Abstrak}

Tujuan penelitian yang ingin dicapai adalah : (1) Menganalisis dan mendiskripsikan pengaruh antara Disiplin Kerja dan Kepuasan Kerja terhadap Kinerja Pegawai Kecamatan Banyumanik Kota Semarang, (2) Menganalisis dan mendeskripsikan pengaruh Disiplin Kerja dan Kepuasan Kerja terhadap Kinerja Pegawai Kecamatan Banyumanik Kota Semarang yang dimoderasi oleh Tambahan Penghasilan Pegawai.

Jenis penelitian ini adalah penelitian eksplanatori atau penelitian yang menjelaskan. Populasi penelitiannya adalah seluruh pegawai di lingkungan Kecamatan Banyumanik Kota Semarang 130 orang. Responden sejumlah 130 orang dipilih menggunakan sensus.

Hasil penelitian dapat disimpulkan : (1) adanya pengaruh antara Disiplin Kerja terhadap Kinerja Pegawai sehingga hipotesis pertama dugaan terbukti atau dapat diterima; (2) adanya pengaruh antara Kepuasan Kerja terhadap Kinerja Pegawai isehingga hipotesis kedua terbukti atau dapat diterima; (3) Tambahan Penghasilan Pegawai sebagai variabel moderating pengaruh Disiplin kerja terhadap Kinerja Pegawai sehingga hipotesis ketiga terbukti atau dapat diterima; dan (4) Tambahan Penghasilan Pegawai sebagai variabel moderating pengaruh Kepuasan Kerja terhadap Kinerja Pegawai sehingga hipotesis keempat terbukti atau dapat diterima. 


\title{
THE EFFECT OF WORK DISCIPLINE AND WORK SATISFACTION ON EMPLOYEE PERFORMANCE WITH ADDITIONAL EMPLOYEE INCOME AS MODERATING VARIABLES
}

\begin{abstract}
The research objectives to be achieved are: (1) Analyzing and describing the influence of Work Discipline and Job Satisfaction on the Performance of Banyumanik Subdistrict Semarang City Employees, (2) Analyzing and describing the effect of Work Discipline and Job Satisfaction on Employees Performance in Banyumanik District Semarang City moderated by Additional Employee Income.

This type of research is explanatory research or research that explains. The research population is all employees in the District Banyumanik Semarang City 130 people. 130 respondents were chosen using the census.

The results of this study can be concluded: (1) there is an influence between work discipline on employee performance so that the first hypothesis is suspected or acceptable; (2) the influence of Job Satisfaction on Employee Performance so that the second hypothesis is proven or acceptable; (3) Additional Employee Income as a moderating variable the influence of work discipline on employee performance so that the third hypothesis is proven or acceptable; and (4) Additional Employee Income as a moderating variable on the effect of Job Satisfaction on Employee Performance so that the fourth hypothesis is proven or acceptable.
\end{abstract}

\footnotetext{
Alamat Korespondensi : Jl. Soekarno Hatta, Pedurungan, Semarang, Jawa ISSN

Tengah 59160

Email : agustinawidya30@gmail.com

1979-4800 (cetak)

2580-8451 (online)
} 


\section{PENDAHULUAN}

Sumber daya manusia merupakan salah satu faktor yang terpenting bagi organisasi karena perannya sebagai subyek pelaksana kebijakan dan kegiatan operasional organisasi. Sumber daya yang dimiliki organisasi seperti modal, metode dan sarana prasarana tidak bisa memberikan hasil yang optimal apabila tidak didukung oleh sumber daya manusia yang mempunyai kinerja yang tinggi. Secanggih apapun teknologi yang dipergunakan dalam suatu organisasi serta sebesar apapun modal organisasi, pada akhirnya sumber daya manusialah yang menjalankannya. Hal ini menunjukkan bahwa tanpa didukung dengan kualitas yang baik sumber daya manusia dalam melaksanakan tugasnya, keberhasilan organisasi tidak akan tercapai.

Dengan dikeluarkannya Undang-Undang Nomor 5 Tahun 2014 tentang Aparatur Sipil Negara, pegawai dituntut mampu untuk mempertanggungjawabkan kinerjanya yang dinilai melalui prestasi dan penilaian kinerja. Pegawai sekarang diharuskan untuk menilai pekerjaannya tiap bulan dan tiap tahun menggunakan SKP (Sasaran Kerja Pegawai) yang menilai sasaran atau kontrak kerja pegawai dalam jangka waktu 1 bulan dan 1 tahun, penilaian capaian kinerja dan perilaku Pegawai Negeri Sipil (PNS). Perubahan standar kualitas kerja tersebut akan merubah budaya kerja yang ada di PNS. Sekarang setiap PNS mempunyai tanggung jawab masing-masing terhadap pekerjaannya dan bagi PNS yang tidak mencapai sasaran kerjanya baik bulanan maupun tahunan akan diperhitungkan dalam tunjangan yang akan diterimanya.

Fenomena yang terjadi di lingkungan Kecamatan Banyumanik Kota Semarang terkait dengan pengelolaan sumber daya manusia yang belum berjalan optimal, terbukti dengan adanya beberapa kegiatan tahun 2016 yang pelaksanaannya tidak sesuai target yang telah ditetapkan, seperti terlihat pada tabel dibawah ini :

Tabel 1. Kegiatan Tahun 2016 Yang Tidak Mencapai Target

\begin{tabular}{|l|l|c|c|c|c|c|}
\hline No & \multicolumn{1}{|c|}{ Nama Kegiatan Satuan } & Target & Real & Capaian & Ket \\
\hline 1. & $\begin{array}{l}\text { Menyiapkan bahan, melaksanakan dan } \\
\text { melaporkan rembug warga, Pra Musrenbang } \\
\text { dan Musrenbang }\end{array}$ & Kegiatan & 1 bulan & $\begin{array}{c}2 \\
\text { bulan }\end{array}$ & $50 \%$ & $\begin{array}{c}\text { Tidak } \\
\text { Tercapai }\end{array}$ \\
\hline 2. & $\begin{array}{l}\text { Kegiatan musyawarah pembangunan desa } \\
\text { Pelaksanaan rapat musyawarah } \\
\text { pembangunan desa }\end{array}$ & Kegiatan & 12 & 9 & $75 \%$ & $\begin{array}{c}\text { Tidak } \\
\text { Tercapai }\end{array}$ \\
\hline 3. & $\begin{array}{l}\text { Kegiatan Penanganan Administrasi } \\
\text { Ketatalaksanaan } \\
\text { Penyusunan regulasi standar pelayanan } \\
\text { Penyusunan SOP Kelurahan }\end{array}$ & Kelurahan & 12 & 9 & $75 \%$ & $\begin{array}{c}\text { Tidak } \\
\text { Tercapai }\end{array}$ \\
\hline
\end{tabular}




\begin{tabular}{|l|l|c|c|c|c|c|}
\hline 4. & $\begin{array}{l}\text { Kegiatan Analisis Jabatan } \\
-\quad \text { Dokumen Analisis Jabatan } \\
- \text { Dokumen Analisis Beban Kerja }\end{array}$ & Jabatan & 3.417 & 2275 & $67 \%$ & $\begin{array}{l}\text { Tidak } \\
\text { Tercapai }\end{array}$ \\
\hline 5. & $\begin{array}{l}\text { Kegiatan Kerja Bakti Massal Kota Semarang } \\
-\quad \begin{array}{l}\text { Pelaksanaan kerja bakti massal tingkat } \\
\text { Kelurahan }\end{array}\end{array}$ & Kelurahan & 22 & 17 & $77 \%$ & $\begin{array}{c}\text { Tidak } \\
\text { Tercapai }\end{array}$ \\
\hline 6. & $\begin{array}{l}\text { Kegiatan kinerja kelurahan dalam kegiatan } \\
\text { pelayanan kepada masyarakat } \\
-\begin{array}{l}\text { Operasional dan sarana prasarana } \\
\text { kelurahan percontohan }\end{array}\end{array}$ & Kelurahan & 3 & 1 & $33 \%$ & $\begin{array}{c}\text { Tidak } \\
\text { Tercapai }\end{array}$ \\
\hline 7. & $\begin{array}{l}\text { Kegiatan meningkatnya tertib administrasi di } \\
\text { kelurahan } \\
-\quad \text { Pelaksanaan monitoring }\end{array}$ & Kegiatan & 48 & 36 & $75 \%$ & $\begin{array}{c}\text { Tidak } \\
\text { Tercapai }\end{array}$ \\
\hline & $\begin{array}{l}\text { Rata-rata Capaian } \\
\text { Tidak } \\
\text { Tercapai }\end{array}$ \\
\hline
\end{tabular}

Sumber : Laporan Kinerja Kecamatan Banyumanik Kota Semarang Tahun 2016

Berdasarkan tabel diatas menunjukkan bahwa di tahun 2016 masih terdapat beberapa kegiatan yang pelaksanaannya tidak sesuai target yang telah ditetapkan. Hal ini terlihat dari capaian real terhadap target yang secara rata-rata hanya mencapai $85 \%$. Hal ini membuktikan bahwa kinerja pegawai Kecamatan Banyumanik Kota Semarang belum optimal, karena pelaksanaan pekerjaan tidak bisa diselesaikan tepat waktu sehingga target tidak dapat tercapai.

Pemerintah Kota Semarang telah mengatur pemberian tambahan penghasilan pegawai melalui Peraturan Walikota Semarang Nomor 139 Tahun 2016 tentang Tambahan Penghasilan Pegawai Bagi Pegawai Negeri Sipil Di Lingkungan Pemerintah Kota Semarang. Dalam pelaksanaannya tambahan penghasilan pegawai diberikan setiap bulan dengan mempertimbangkan kedisiplinan pegawai melalui absensi kehadiran dan penilaian kerja melalui Sasaran Kerja Pegawai (SKP) bulanan masing-masing pegawai oleh atasan langsung. Tingkat kehadiran dan penilaian Sasaran Kerja Pegawai (SKP) akan mempengaruhi besaran tambahan penghasilan pegawai yang akan diterima oleh pegawai.

Tugas manajemen sumber daya manusia berkisar pada upaya mengelola unsur manusia dengan potensi yang dimiliki sehingga dapat diperoleh sumber daya manusia yang puas (satisfied) dan memuaskan (satisfactory) bagi organisasi. Kepuasan kerja adalah suatu perasaan yang menyokong atau tidak menyokong diri pegawai yang berhubungan dengan pekerjaannya maupun dengan kondisi dirinya (Keith DavisWexley dan Yuki dalam Mangkunegoro, 2013). Salah satu tujuan bekerja adalah memperoleh kepuasan kerja. Perasaan yang berhubungan dengan pekerjaan melibatkan aspek-aspek seperti upah atau gaji yang diterima, kesempatan pengembangan karier, hubungan dengan pegawai lainnya, penempatan kerja, jenis pekerjaan, 
struktur organisasi perusahaan dan mutu pengawasan. Sedangkan perasaan yang berhubungan dengan dirinya antara lain umur, kondisi kesehatan, kemampuan dan pendidikan. Orang akan merasa puas apabila tidak ada perbedaan (discrepanscy) antara yang diinginkan dengan persepsinya akan kenyataan. Meskipun terdapat perbedaan akan tetapi kalau perbedaan positif maka orang atau pegawai akan merasa puas, demikian juga sebaliknya. Pegawai akan merasa puas bila mendapat sesuatu yang dibutuhkan. Kepuasan kerja merupakan refleksi dari perasaan dan sikap individu tarhadap pekerjaannya, yang merupakan interaksi antara yang bersangkutan dengan tempat kerjanya. Individu dengan kepuasan kerja diharapkan akan mengeluarkan seluruh kemampuan dan energi yang dimiliki untuk menyelesaikan pekerjaan, sehingga dapat menghasilkan kinerja yang optimal bagi organisasi. Kepuasan seorang pegawai akan berakibat kinerjanya meningkat. Hasil penelitian dari Saputra, Bagia, Yulianthini (2016) bahwa Kepuasan kerja berpengaruh terhadap Kinerja Pegawai. Sebaliknya hasil penelitian Hentry Sukmasari (2011) justru menyatakan bahwa Kepuasan kerja tidak berpengaruh terhadap Kinerja Pegawai. Tujuan penelitian yang ingin dicapai adalah : (1) Menganalisis dan mendiskripsikan pengaruh antara Disiplin Kerja dan Kepuasan Kerja terhadap Kinerja Pegawai Kecamatan Banyumanik Kota Semarang, (2) Menganalisis dan mendeskripsikan pengaruh Disiplin Kerja dan Kepuasan Kerja terhadap Kinerja Pegawai Kecamatan Banyumanik Kota Semarang yang dimoderasi oleh Tambahan Penghasilan Pegawai.

Tabel 2 Research Gap

\begin{tabular}{|c|c|c|c|}
\hline No & Issue Gap & Peneliti & Hasil \\
\hline 1. & $\begin{array}{l}\text { Pengaruh Disiplin Kerja } \\
\text { Terhadap Kinerja Pegawai }\end{array}$ & $\begin{array}{lll}\text { 1. } & \text { Heni } & \text { Sidanti } \\
& (2015) \\
\text { 2. } & \text { Jessica Martha } \\
& \text { Kusuma } \\
(2013)\end{array}$ & $\begin{array}{l}\text { Disiplin Kerja berpengaruh positif } \\
\text { dan signifikan terhadap Kinerja } \\
\text { Pegawai }\end{array}$ \\
\hline 2. & $\begin{array}{lr}\text { Pengaruh } & \text { Disiplin Kerja } \\
\text { Terhadap } & \text { Kinerja } \\
\text { Karyawan } & \\
\end{array}$ & $\begin{array}{l}\text { Agung } \quad \text { Setiawan } \\
(2013)\end{array}$ & $\begin{array}{l}\text { Disiplin Kerja tidak berpengaruh } \\
\text { terhadap Kinerja Karyawan }\end{array}$ \\
\hline 3. & $\begin{array}{l}\text { Pengaruh Kepuasan Kerja } \\
\text { Terhadap Kinerja Pegawai }\end{array}$ & $\begin{array}{l}\text { 1. Saputra, Bagia, } \\
\text { Yulianthini (2016) } \\
\text { 2. Novita Marlia } \\
(2010)\end{array}$ & $\begin{array}{l}\text { Kepuasan kerja berpengaruh } \\
\text { terhadap Kinerja Pegawai. }\end{array}$ \\
\hline 4. & $\begin{array}{l}\text { Pengaruh Kepuasan Kerja } \\
\text { Terhadap Kinerja Pegawai }\end{array}$ & $\begin{array}{l}\text { Hentry } \\
(2011)\end{array} \quad$ Sukmasari & $\begin{array}{l}\text { Kepuasan kerja tidak berpengaruh } \\
\text { terhadap Kinerja Pegawai. }\end{array}$ \\
\hline
\end{tabular}

Sumber : Jurnal dan penelitian terdahulu 
Berdasarkan tabel 1.2 terlihat bahwa penelitian terdahulu hasilnya terdapat perbedaan khususnya variabel disiplin kerja dan kepusan terhadap kinerja pegawai. Menurut Anthony dan Govindarajan (2007) untuk mengatasi hasil penelitian yang berbeda dan bertentangan perlu adanya pendekatan kontijensi yang mengungkapkan bahwa hubungan diantara berbagai variabel yang diteliti dipengaruhi oleh variabel lain yang bersifat kondisional. Pendekatan kontijensi ini memungkinkan varibel lain bertindak sebagai intervening atau moderating. Berdasarkan fenomena yang terjadi dan research gap penelitian diatas, maka perlu dilakukan penelitian dengan menambahkan faktor Tambahan Penghasilan Pegawai sebagai variabel moderatingnya.

\section{TELAAH PUSTAKA}

\section{Kinerja}

Kinerja merupakan hasil kerja secara kualitas dan kuantitas yang dapat dicapai oleh seorang pegawai dalam melaksanakan tugas sesuai dengan tanggung jawab yang diberikan kepadanya. Menurut Dessler dalam Primasari (2013) kinerja (performance) merupakan prestasi kerja dari perbandingan antara hasil kerja yang secara nyata dengan standart kerja yang ditetapkan dengan lebih memfokuskan pada hasil kerjanya. Definisi kerja menurut Bambang Kusriyanto dalam Mangkunegara (2013) adalah perbandingan hasil yang dicapai dengan peran serta tenaga kerja per satuan waktu (lazimnya per jam). Faustino Cardosa Gomes dalam Mangkunegara (2013) mengemukakan definisi kinerja sebagai ungkapan seperti output, efisiensi serta efektifitas sering dihubungkan dengan produktivitas. Sedangkan menurut Mangkunegara (2013), kinerja karyawan (prestasi kerja) adalah hasil kerja secara kualitas dan kuantitas yang dicapai oleh seorang karyawan dalam melaksanakan tugasnya sesuai dengan tanggung jawab yang diberikan kepadanya. Oleh karena itu dapat disimpulkan bahwa kinerja Sumber Daya Manusia adalah prestasi kerja, atau hasil kerja (output) baik kualitas maupun kuantitas yang dicapai SDM per satuan periode waktu dalam melaksanakan tugas kerjanya sesuai dengan tanggung jawab yang diberikan kepadanya. Penilaian prestasi kerja merupakan usaha yang dilakukan pimpinan untuk menilai hasil kerja bawahannya. Penilaian kinerja adalah memberikan umpan balik kepada pegawai dengan tujuan untuk memotivasi orang tersebut untuk menghilangkan kemerosotan kinerja atau berkinerja lebih tinggi lagi. 


\section{Disiplin Kerja}

Disiplin merupakan modal yang diperlukan untuk mencapai tujuan yang diinginkan. Sehingga keberadaan disiplin kerja sangat diperlukan dalam suatu organisasi, karena dengan disiplin sebuah organisasi akan dapat melaksanakan program-program kerjanya untuk mencapai sasaran yang telah ditetapkan. Anggota yang disiplin dan menaati tata tertib, menaati semua norma-norma dan peraturan yang berlaku dalam organisasi akan dapat meningkatkan efektivitas dan produktivitas. Sedangkan organisasi yang memiliki anggota yang tidak disiplin akan susah untuk merealisasikan pencapaian tujuan yang telah ditetapkan sebelumnya. Seorang pemimpin yang baik harus berusaha agar para bawahannya mempunyai disiplin yang baik dan juga harus dapat memberikan contoh dalam menjalankan disiplin yang baik dalam suatu organisasi.

Menurut Singodimedjo dalam Sutrisno (2015) mengemukakan disiplin adalah sikap kesediaan dan kerelaan seseorang untuk mematuhi dan menaati norma-norma peraturan yang berlaku disekitarnya. Disiplin karyawan yang baik akan mempercepat tujuan perusahaan, sedangkan disiplin yang merosot akan menjadi penghalang dan memperlambat pencapaian tujuan perusahaan.

Disiplin berarti tindakan yang diambil dengan penyeliaan untuk mengoreksi perilaku dan sikap yang salah pada karyawan (Siagian dalam Sutrisno, 2015). Bentuk disiplin yang baik akan tercermin pada suasana yaitu :

a. Tingginya rasa kepedulian karyawan terhadap pencapaian tujuan perusahaan.

b. Tingginya semangat dan gairah kerja dan inisiatif para karyawan dalam melakukan pekerjaan.

c. Besarnya rasa tanggung jawab para karyawan untuk melaksanakan tugas dengan sebaikbaiknya.

d. Berkembangnya rasa memiliki dan rasa solidaritas yang tinggi dikalangan karyawan.

e. Meningkatnya efisiensi dan produktivitas kerja para karyawan.

Menurut Terry dalam Sutrisno (2015) disiplin merupakan alat penggerak karyawan. Agar tiap pekerjaan dapat berjalan dengan lancar, maka harus diusahakan agar ada disiplin yang baik. Terry kurang setuju jika disiplin hanya dihubungkan dengan hal-hal yang kurang menyenangkan (hukuman), karena sebenarnya hukuman merupakan alat paling akhir untuk menegakkan disiplin. 


\section{Tambahan Penghasilan Pegawai atau Insentif}

Tambahan Penghasilan Pegawai atau insentif sebagai sarana motivasi yang mendorong para pegawai untuk bekerja dengan kemampuan yang optimal, yang dimaksudkan sebagai pendapatan ekstra di luar gaji yang telah ditentukan. Pemberian tambahan penghasilan pegawai atau insentif dimaksudkan agar dapat memenuhi kebutuhan para pegawai dan keluarga mereka. Tambahan penghasilan pegawai atau insentif dapat diartikan sebagai balas jasa yang memadai kepada pegawai yang prestasinya melebihi standar yang telah ditetapkan. Tambahan penghasilan pegawai atau insentif merupakan suatu faktor pendorong bagi pegawai untuk bekerja lebih baik agar kinerja pegawai dapat meningkat.

Menurut Ranupandoyo, dkk dalam Mangkunegara (2013), mengemukakan bahwa insentif adalah suatu bentuk motivasi yang dinyatakan dalam bentuk uang atas dasar kinerja yang tinggi dan juga merupakan rasa pengakuan dari pihak organisasi terhadap kinerja karyawan dan kontribusi terhadap organisasi. Sujak dalam Mangkunegara (2013), berpendapat bahwa penghargaan berupa insentif atas dasar prestasi kerja yang tinggi merupakan rasa pengakuan dari pihak organisasi terhadap prestasi karyawan dan kontribusi kepada organisasi. Sedangkan menurut Handoko dalam Mangkunegara (2013), mengemukakan bahwa insentif adalah upaya untuk meningkatkan motivasi karyawan dalam upaya mencapai tujuan-tujuan organisasi.

Jadi menurut pendapat-pendapat para ahli di atas dapat disimpulkan, bahwa Tambahan Penghasilan Pegawai atau insentif adalah dorongan pada seseorang agar mau bekerja dengan lebih baik dan agar lebih dapat mencapai tingkat kinerja yang lebih tinggi sehingga dapat membangkitkan gairah kerja dan motivasi seorang pegawai. Jadi seseorang mau bekerja dengan baik apabila dalam dirinya terdapat motivasi. Yang menjadi masalah adalah bagaimana menciptakan gairah kerja dan motivasinya, sebab walaupun motivasi sudah terbentuk apabila tidak tidak disertai dengan gairah kerjanya maka tetap saja pegawai tersebut tidak akan bisa bekerja sesuai yang diharapkan.

\section{Kepuasan Kerja}

Kepuasan kerja pada dasarnya merupakan sesuatu yang bersifat individual. Setiap individu memiliki tingkat kepuasan yang berbeda-beda sesuai dengan sistem nilai yang berlaku pada dirinya. Kepuasan kerja merupakan evaluasi yang menggambarkan seseorang atas perasaan sikapnya senang atau tidak senang, puas atau tidak puas dalam bekerja. 
Davis dalam Mangkunegara (2013) mengemukakan kepuasan kerja adalah perasaan yang menyokong atau tidak menyokong yang dialami pegawai dalam bekerja. Menurut Wexley dan Yuki dalam Mangkunegara (2013), kepuasan kerja adalah cara pegawai merasakan dirinya atau pekerjaannya. Menurut Siagian dalam Setyowati (2014), kepuasan kerja merupakan suatu cara pandang seseorang baik yang bersifat positif maupun negatif tentang pekerjaannya. Sedangkan menurut Handoko dalam Sutrisno (2015) mengemukakan kepuasan kerja adalah keadaan emosional yang menyenangkan atau tidak menyenangkan bagi para karyawan memandang pekerjaan mereka. Kepuasan kerja mencerminkan perasaan seseorang terhadap pekerjaannya. Ini tampak dari sikap positif karyawan terhadap pekerjaan dan segala sesuatu yang dihadapi di lingkungan kerjanya.

Kepuasan kerja adalah cermin dari perasaan seseorang terhadap pekerjaannya. Robbin dalam Setyowati (2014), mendifinisikan kepuasan kerja adalah suatu sikap umum seorang individu terhadap pekerjaannya, selisih antara banyaknya ganjaran yang diterima seorang pekerja dan banyaknya yang mereka yakini seharusnya mereka terima.

\section{Hubungan Disiplin Kerja Terhadap Kinerja Pegawai}

Singodimedjo dalam Sutrisno (2015) mengatakan disiplin adalah sikap kesediaan dan kerelaan seseorang untuk mematuhi dan menaati norma-norma peraturan yang berlaku disekitarnya. Disiplin karyawan yang baik akan mempercepat tujuan perusahaan, sedangkan disiplin yang merosot akan menjadi penghalang dan memperlambat pencapaian tujuan perusahaan.

Disiplin merupakan modal yang diperlukan diperlukan dalam suatu organisasi, karena dengan disiplin sebuahuntuk mencapai tujuan yang diinginkan. Sehingga keberadaan disiplin kerja sangat diperlukan dalam suatu organisasi, karena dengan disiplin sebuah organisasi akan dapat melaksanakan program-program kerjanya mencapai sasaran yang telah ditetapkan. Disiplin kerja merupakan sikap yang sangat diperlukan oleh setiap orang dalam usaha untuk meningkatkan kinerja guna mencapai tujuan organisasi. Penerapan disiplin bagi karyawan diharapkan dapat meningkatkan kinerja karyawan disamping itu perlu didukung lingkungan kerja

yang baik yaitu lingkungan kerja yang dapat menunjang kelancaran, keselamatan, kebersihan dan kenyamanan dalam bekerja dan adanya fasilitas-fasilitas yang memadai sehingga pegawai 
merasa aman, tenang dan senang dalam menjalankan tugas-tugas yang menjadi tanggungjawabnya.

Penelitian Sidanti (2015), menyatakan bahwa disiplin kerja mempunyai pengaruh paling dominan terhadap kinerja pegawai, sehingga dengan adanya disiplin kerja maka kinerja karyawan akan meningkat dan penelitian Kusuma (2013) juga menyatakan bahwa variabel disiplin kerja berpengaruh positif dan signifikan terhadap kinerja karyawan.

Dari uraian diatas dapat ditarik hipotesis sebagai berikut :

H1: Disiplin Kerja berpengaruh terhadap Kinerja Pegawai

\section{Hubungan Kepuasan Kerja Terhadap Kinerja Pegawai}

Ostroff dalam Sutrini (2015) mengemukakan bahwa kepuasan kerja mempunyai hubungan yang signifikan dengan kinerja, selanjutnya karyawan yang merasa terpuaskan terhadap pekerjaaan biasanya bekerja lebih keras dan lebih baik dibandingkan karyawan yang mengalami stres dan tidak terpuaskan terhadap pekerjaannya. Kepuasan dan sikap karyawan merupakan hal yang penting dalam menentukan perilaku dan respon terhadap pekerjaannya. Melalui ini organisasi yang efektif akan tercapai.

Lawyer dalam Sutrini (2015), mengatakan kepuasan kerja tergantung kesesuaian atau keseimbangan antara yang diharapkan dengan kenyataan. Indikasi kepuasan kerja dapat dikaitkan dengan tingkat absensi, disiplin kerja, loyalitas dan konflik di lingkungan kerja. Halhal tersebut mempengaruhi kinerja pegawai dan efektivitas karyawan.

Hasil penelitian Khairiyah, dkk (2013), menunjukkan hubungan positif dan signifikan antara kepuasan kerja dengan kinerja pegawai dan Putri, dkk (2013) menyatakan bahwa kepuasan kerja juga berpengaruh positif terhadap kinerja karyawan.

Dari uraian diatas dapat ditarik hipotesis sebagai berikut :

H2 : Kepuasan Kerja berpengaruh terhadap Kinerja Pegawai

\section{Hubungan Disiplin Kerja Terhadap Kinerja Pegawai dengan moderasi Tambahan Penghasilan Pegawai}

Disiplin kerja merupakan sikap yang sangat diperlukan oleh setiap orang dalam usaha untuk meningkatkan kinerja guna mencapai tujuan organisasi. Penerapan disiplin bagi karyawan diharapkan dapat meningkatkan kinerja karyawan disamping itu perlu didukung lingkungan kerja 
yang baik yaitu lingkungan kerja yang dapat menunjang kelancaran, keselamatan, kebersihan dan kenyamanan dalam bekerja dan adanya fasilitas-fasilitas yang memadai sehingga pegawai merasa aman, tenang dan senang dalam menjalankan tugas-tugas yang menjadi tanggungjawabnya. Kusuma (2013) juga menyatakan bahwa variabel disiplin kerja berpengaruh positif dan signifikan terhadap kinerja karyawan.

Program pemberian tambahan penghasilan pegawai yaitu memberikan bayaran tambahan berdasarkan kinerja dari pegawai. Tujuan utama program pemberian tambahan penghasilan pegawai adalah untuk mendorong kinerja dan efektivitas pegawai.

Hasil penelitian Indra Lestari Sumbung, dkk (2015), menunjukkan bahwa insentif (TPP) dapat memperkuat hubungan antara pengaruh disipilin kerja terhadap kinerja pegawai.

Dari uraian diatas dapat ditarik hipotesis sebagai berikut :

H3 : Tambahan Penghasilan Pegawai dapat memoderasi pengaruh Disiplin Kerja terhadap Kinerja Pegawai

\section{Hubungan Pengaruh Kepuasan Kerja Terhadap Kinerja Pegawai dengan moderasi Tambahan Penghasilan Pegawai}

Desakan pemenuhan kebutuhan yang diinginkan seorang pegawai dapat memacu seorang pegawai untuk meningkatkan kinerja, sehingga tambahan penghasilan pegawai dapat merangsang mereka untuk bekerja secara efisien dan efektif sehingga dapat tercapai kinerja yang diinginkan. Kepuasan dan sikap karyawan merupakan hal yang penting dalam menentukan perilaku dan respon terhadap pekerjaannya. Melalui ini organisasi yang efektif akan tercapai.

Lawyer dalam Sutrini (2015), mengatakan kepuasan kerja tergantung kesesuaian atau keseimbangan antara yang diharapkan dengan kenyataan.Sujak dalam Mangkunegara (2013) berpendapat bahwa penghargaan berupainsentif atas dasar prestasi kerja yang tinggi merupakan rasa pengakuan dari pihak organisasi terhadap prestasi pegawai dan kontribusi kepada organisasi. Sedangkan menurut Handoko dalam Mangkunegara (2013), mengemukakan bahwa insentif adalah upaya untuk meningkatkan motivasi pegawai dalam upaya mencapai tujuan-tujuan organisasi.

Sehingga dapat dikatakan tambahan penghasilan pegawai adalah tambahan penghasilan diluar gaji yang diberikan oleh instansi. Program pemberian tambahan penghasilan pegawai yaitu memberikan bayaran tambahan berdasarkan kinerja dari pegawai. Tujuan utama program 
pemberian tambahan penghasilan pegawai adalah untuk mendorong kinerja dan efektivitas pegawai. Yang perlu diperhatikan dan dipertimbangkan dalam pemberian tambahan penghasilan pegawai adalah adil, dapat diterimakan, memuaskan, memberi motivasi kerja, bersifat penghargaan dan sesuai dengan kebutuhan.

Hasil penelitian Yunita Sari dan M. Al Musadieq (2017), menunjukkan bahwa insentif (TPP) dapat memperkuat hubungan antara pengaruh kepuasan kerja terhadap kinerja pegawai Dari uraian diatas dapat ditarik hipotesis sebagai berikut :

H4 : Tambahan Penghasilan Pegawai dapat memoderasi Pengaruh Kepuasan Kerja terhadap Kinerja Pegawai

\section{HASIL DAN PEMAHASAN}

Uji validitas bertujuan untuk mengukur sah atau valid tidaknya suatu kuesioner, suatu kuesioner dinyatakan valid jika pertanyaan pada kuesioner mampu untuk mengungkapkan sesuatu yang akan diukur oleh kuesioner tersebut Adapun pengujian variabel penelitian adalah sebagai berikut:

Tabel 3. Hasil Uji Validitas Instrumen Penelitian

\begin{tabular}{|c|c|c|c|c|}
\hline Variabel & Indikator & r hitung & r tabel & Ket. \\
\hline \multirow{5}{*}{$\begin{array}{l}\text { Disiplin } \\
\text { Kerja } \\
\text { (X1) }\end{array}$} & $\begin{array}{l}\text { Kehadiran pada hari-hari kerja } \\
\text { (X1.1) }\end{array}$ & 0,731 & 0,244 & Valid \\
\hline & $\begin{array}{l}\text { Ketepatan jadwal masuk dan } \\
\text { pulang kerja (X1.2) }\end{array}$ & 0,737 & 0,244 & Valid \\
\hline & $\begin{array}{l}\text { Ketaatan terhadap peraturan- } \\
\text { peraturan yang telah ditentukan } \\
(\mathrm{X} 1.3)\end{array}$ & 0,655 & 0,244 & Valid \\
\hline & $\begin{array}{l}\text { Menaati prosedur kerja yang telah } \\
\text { ditentukan (X1.4) }\end{array}$ & 0,873 & 0,244 & Valid \\
\hline & $\begin{array}{l}\text { Melaksanakan segala tugas dan } \\
\text { kewajiban yang sudah ditentukan } \\
\text { (X1.5) }\end{array}$ & 0,534 & 0,244 & Valid \\
\hline \multirow{2}{*}{$\begin{array}{c}\text { Kepuasan } \\
\text { Kerja (X2) }\end{array}$} & Kepuasan terhadap gaji (X2.1) & 0,955 & 0,244 & Valid \\
\hline & Kepuasan dengan promosi (X2.2) & 0,925 & 0,244 & Valid \\
\hline
\end{tabular}




\begin{tabular}{|c|l|c|c|c|}
\hline & $\begin{array}{l}\text { Kepuasan terhadap rekan kerja } \\
\text { (X2.3) }\end{array}$ & 0,644 & 0,244 & Valid \\
\hline $\begin{array}{c}\text { Tambahan } \\
\text { Penghasilan } \\
\text { Pegawai (M) }\end{array}$ & $\begin{array}{l}\text { Saya merasa tunjangan financial } \\
\text { yang diterima sudah sesuai dengan } \\
\text { pengorbanan yang dilakukan } \\
\text { (M1.1) }\end{array}$ & 0,406 & 0,244 & Valid \\
\cline { 2 - 5 } & $\begin{array}{l}\text { Saya merasa tunjangan non } \\
\text { finansial setiap tahunnya, dapat } \\
\text { menjamin kebutuhan keluarga } \\
\text { (M1.2) }\end{array}$ & 0,759 & 0,244 & Valid \\
\hline $\begin{array}{c}\text { Kinerja } \\
\text { Pegawai (Y) }\end{array}$ & $\begin{array}{l}\text { Kualitas kerja saya jauh lebih baik } \\
\text { dari pegawai lain (Y1.1) }\end{array}$ & 0,816 & 0,244 & Valid \\
\cline { 2 - 5 } & $\begin{array}{l}\text { Kuantitas kerja saya melebihi rata- } \\
\text { rata pegawai lain (Y1.2) }\end{array}$ & 0,756 & 0,244 & Valid \\
\cline { 2 - 5 } & $\begin{array}{l}\text { Saya memiliki ketepatan yang } \\
\text { bagus dalam melaksanakan } \\
\text { pekerjaan (Y1.3) }\end{array}$ & 0,516 & 0,244 & Valid \\
\cline { 2 - 5 } & $\begin{array}{l}\text { Efektivitas kerja saya melebihi rata- } \\
\text { rata pegawai lain (Y1.4) }\end{array}$ & 0,872 & 0,244 & Valid \\
\hline
\end{tabular}

Sumber Data : Data primer yang diolah, 2018

Berdasarkan tabel di atas diketahui semua indikator variabel disiplin kerja $\left(\mathrm{X}_{1}\right)$ dan kepuasan kerja $\left(\mathrm{X}_{2}\right)$, Tambahan penghasilan pegawai $(\mathrm{M})$ dan kinerja pegawai $(\mathrm{Y})$ valid karena memiliki nilai $r$ hitung $>r$ tabel.

Uji reliabilitas merupakan alat untuk mengukur suatu kuesioner yang merupakan indikator dari variabel. Adapun pengujian reliabilitas variabel penelitian adalah sebagai berikut:

Tabel 4. Pengujian Reliabilitas Variabel-variabel Penelitian

\begin{tabular}{|l|c|c|c|}
\hline \multicolumn{1}{|c|}{ Variabel } & $\begin{array}{c}\text { Alpha } \\
\text { Cronbach }\end{array}$ & $\begin{array}{c}\text { Angka Standar } \\
\text { Reliabel }\end{array}$ & Kriteria \\
\hline Disiplin Kerja $\left(\mathrm{X}_{1}\right)$ & 0,85 & 0,7 & Reliabel \\
\hline Kepuasan Kerja $\left(\mathrm{X}_{2}\right)$ & 0,809 & 0,7 & Reliabel \\
\hline Tambahan Penghasilan Pegawai (M) & 0,719 & 0,7 & Reliabel \\
\hline Kinerja Pegawai (Y) & 0,718 & 0,7 & Reliabel \\
\hline
\end{tabular}


Sumber Data : Data primer yang diolah, 2018

Pada uji reliabilitas tabel di atas variabel disiplin kerja $\left(\mathrm{X}_{1}\right)$, kepuasan kerja $\left(\mathrm{X}_{2}\right)$, tambahan penghasilan pegawai (M) dan kinerja pegawai (Y) dikatakan reliabel karena Alpha Cronbach $>0,7$ sehingga layak untuk diujikan ke pengujian selanjutnya.

Uji Normalitas adalah sebuah uji untuk mengetahui apakah model regresi variabel dependen dan variabel independen atau keduanya mempunyai distribusi normal atau tidak dapat dilihat menggunakan uji Kolmogorov Smirnov.

1. Pengaruh disiplin kerja dan kepuasan kerja terhadap kinerja pegawai

Tabel 5 Hasil Pengujian Normalitas Persamaan I

Pengaruh disiplin kerja dan kepuasan kerja terhadap kinerja pegawai

\section{One-Sample Kolmogorov-Smirnov Test}

\begin{tabular}{|ll|r|}
\hline & & $\begin{array}{c}\text { Unstandardized } \\
\text { Residual }\end{array}$ \\
\hline Normal Parameters ${ }^{\mathrm{a}}$ & Mean & 130 \\
& Std. Deviation & .0000000 \\
Most Extreme Differences & Absolute & 1.83859779 \\
& Positive & .115 \\
& Negative & .093 \\
& & -.115 \\
Kolmogorov-Smirnov Z & & .922 \\
Asymp. Sig. (2-tailed) & & .366 \\
\hline
\end{tabular}

a. Test distribution is Normal.

Sumber Data : Data primer yang diolah, 2018

Berdasarkan tabel diatas diketahui bahwa uji normalitas persamaan I pengaruh disiplin kerja dan kepuasan kerja terhadap kinerja pegawai tingkat signifikan variabel penelitian 0,366 > 0,05 maka model regresi terdistribusi normal, oleh sebab itu dapat dilakukan pengujian selanjutnya. 
2. Pengaruh disiplin kerja dan kepuasan kerja terhadap kinerja pegawai dengan moderasi tambahan penghasilan pegawai

Tabel 6. Hasil Pengujian Normalitas Persamaan II

Pengaruh disiplin kerja dan kepuasan kerja terhadap kinerja pegawai dengan moderasi tambahan penghasilan pegawai

\section{One-Sample Kolmogorov-Smirnov Test}

\begin{tabular}{|ll|r|}
\hline & & $\begin{array}{c}\text { Unstandardized } \\
\text { Residual }\end{array}$ \\
Normal Parameters ${ }^{\mathrm{a}} \quad$ Mean & 130 \\
& Std. Deviation & .0000000 \\
Most Extreme Differences & Absolute & .99355929 \\
& Positive & .163 \\
& Negative & -.163 \\
Kolmogorov-Smirnov $\mathrm{Z}$ & & 1.307 \\
Asymp. Sig. (2-tailed) & & .067 \\
\hline
\end{tabular}

a. Test distribution is Normal.

Sumber Data : Data primer yang diolah, 2018

Berdasarkan tabel diatas diketahui bahwa uji normalitas persamaan II Pengaruh disiplin kerja dan kepuasan kerja terhadap kinerja pegawai dengan moderasi tambahan penghasilan pegawai tingkat signifikan variabel penelitian 0,067 > 0,05 maka model regresi terdistribusi normal, oleh sebab itu dapat dilakukan pengujian selanjutnya.

\section{Uji Heteroskedastisitas}

Uji ini bertujuan untuk menguji apakah dalam model regresi terjadi ketidaksamaan variance dari residual satu pengamatan ke pengamatan lain. Model regresi yang baik maka tidak terjadi heteroskedastisitas. 
1. Pengaruh disiplin kerja dan kepuasan kerja terhadap kinerja pegawai

Tabel 7. Pengaruh disiplin kerja dan kepuasan kerja terhadap kinerja pegawai

\section{Coefficients $^{\mathrm{a}}$}

\begin{tabular}{|l|r|r|r|r|r|}
\hline \multirow{2}{*}{ Model } & \multicolumn{2}{|c|}{$\begin{array}{c}\text { Unstandardized } \\
\text { Coefficients }\end{array}$} & $\begin{array}{r}\text { Standardized } \\
\text { Coefficients }\end{array}$ & & \\
\cline { 2 - 5 } & \multicolumn{1}{|c|}{$\mathrm{B}$} & Std. Error & \multicolumn{1}{c|}{ Beta } & \multicolumn{1}{c|}{$\mathrm{t}$} & \multicolumn{1}{c|}{ Sig. } \\
\hline $1 \quad$ (Constant) & 2.573 & 1.017 & & 3.456 & .218 \\
& -.121 & .017 & -.172 & -1.421 & .192 \\
Disiplin Kerja & .005 & .064 & .014 & .200 & .931 \\
Kepuasan Kerja & & & & & \\
\hline
\end{tabular}

a. Dependent Variable:

abs 1

Sumber Data : data olahan SPSS, 2018

Berdasarkan tabel diatas pengolahan data diatas diketahi bahwa hasil nilai signifikansi > 0,05 maka dapat disimpulkan bahwa tidak terjadi heteroskedastisitas.

2. Pengaruh disiplin kerja dan kepuasan kerja terhadap kinerja pegawai dengan moderasi tambahan penghasilan pegawai

Tabel 8. Pengaruh disiplin kerja dan kepuasan kerja terhadap kinerja pegawai dengan moderasi tambahan penghasilan pegawai

\section{Coefficients $^{\mathrm{a}}$}

\begin{tabular}{|c|c|c|c|c|c|}
\hline \multirow[b]{2}{*}{ Model } & \multicolumn{2}{|c|}{$\begin{array}{l}\text { Unstandardized } \\
\text { Coefficients }\end{array}$} & \multirow{2}{*}{$\begin{array}{c}\begin{array}{c}\text { Standardized } \\
\text { Coefficients }\end{array} \\
\text { Beta }\end{array}$} & \multirow[b]{2}{*}{$\mathrm{t}$} & \multirow[b]{2}{*}{ Sig. } \\
\hline & B & Std. Error & & & \\
\hline $1 \quad$ (Constant) & 5.654 & 3.643 & & 2.761 & .084 \\
\hline Disiplin Kerja & -.189 & .176 & -.966 & -1.274 & .345 \\
\hline Kepuasan Kerja & -.204 & .283 & -.387 & -.666 & .574 \\
\hline
\end{tabular}




\begin{tabular}{|c|c|c|c|c|c|}
\hline $\begin{array}{l}\text { Tambahan } \\
\text { Penghasilan } \\
\text { Pegawai }\end{array}$ & .202 & .261 & .473 & .634 & .539 \\
\hline $\begin{array}{l}\text { Interaksi DK } \\
\text { dengan TPP }\end{array}$ & .000 & .006 & .210 & .072 & . \\
\hline $\begin{array}{l}\text { Interaksi KK } \\
\text { dengan TPP }\end{array}$ & .000 & .013 & .031 & .028 & .98 \\
\hline
\end{tabular}

a. Dependent Variable: abs2

Sumber Data : data olahan SPSS, 2018

Berdasarkan tabel diatas pengolahan data diatas diketahi bahwa hasil nilai signifikansi > 0,05 maka dapat disimpulkan bahwa tidak terjadi heteroskedastisitas.

\section{Uji Multikolineritas}

Pengujian ini untuk mengetahui adanya hubungan linear yang "sempurna" atau pasti di antara beberapa atau semua variabel independen yang menjelaskan model regresi. Model regresi yang baik seharusnya tidak terjadi korelasi di antara variabel independen

1. Pengaruh disiplin kerja dan kepuasan kerja terhadap kinerja pegawai

Tabel 9. Pengaruh disiplin kerja dan kepuasan kerja terhadap kinerja pegawai

\begin{tabular}{|l|r|r|}
\hline \multirow{2}{*}{ Model } & \multicolumn{2}{|c|}{$\begin{array}{c}\text { Collinearity } \\
\text { Statistics }\end{array}$} \\
\cline { 2 - 3 } & Tolerance & VIF \\
\hline $1 \quad$ (Constant) & & \\
Disiplin Kerja & .948 & 1.067 \\
& & \\
Kepuasan Kerja & .948 & 1.067 \\
\hline
\end{tabular}

Sumber Data : data olahan SPSS, 2018

Berdasarkan hasil tabel diatas menunjukkan bahwa semua nilai tolerance lebih besar dari nilai default yang ditentukan sebesar 0,10. Sedangkan untuk nilai VIF juga menunjukkan di bawah angka 10 sehingga dapat disimpulkan bahwa semua variable telah 
memenuhi persyaratan ambang toleransi dan nilai VIF, artinya bahwa variable bebas terhadap variable terikat tidak terjadi problem multikolinieritas

2. Pengaruh disiplin kerja dan kepuasan kerja terhadap kinerja pegawai dengan moderasi tambahan penghasilan pegawai

Tabel 10. Pengaruh disiplin kerja dan kepuasan kerja terhadap kinerja pegawai dengan moderasi tambahan penghasilan pegawai

\begin{tabular}{|c|c|c|}
\hline \multirow[b]{2}{*}{ Model } & \multicolumn{2}{|c|}{$\begin{array}{c}\text { Collinearity } \\
\text { Statistics }\end{array}$} \\
\hline & $\begin{array}{c}\text { Toleranc } \\
\mathrm{e}\end{array}$ & VIF \\
\hline 1 (Constant) & & \\
\hline Disiplin Kerja & .513 & 6.598 \\
\hline Kepuasan Kerja & .731 & 3.035 \\
\hline $\begin{array}{l}\text { Tambahan } \\
\text { Penghasilan } \\
\text { Pegawai }\end{array}$ & .923 & 4.499 \\
\hline $\begin{array}{l}\text { Interaksi DK } \\
\text { dengan TPP }\end{array}$ & .904 & 6.007 \\
\hline $\begin{array}{l}\text { Interaksi KK } \\
\text { dengan TPP }\end{array}$ & .813 & 1.816 \\
\hline
\end{tabular}

Sumber Data : data olahan SPSS, 2018

Berdasarkan hasil diatas menunjukkan bahwa semua nilai tolerance lebih besar dari nilai default yang ditentukan sebesar 0,10. Sedangkan untuk nilai VIF juga menunjukkan di bawah angka 10. Sehingga dapat disimpulkan bahwa semua variabel telah memenuhi persyaratan ambang toleransi dan nilai VIF, artinya bahwa variabel bebas terhadap variable terikat tidak terjadi problem multikolinieritas. 


\section{Uji Regresi Linier}

\section{Tahap 1 Regresi Linier Berganda}

Tahap I merupakan analisis regresi ganda untuk menguji pengaruh disiplin kerja dan kepuasan kerja terhadap kinerja pegawai. Dalam analisis ini diperoleh standardized coefisien yang menunjukkan koefisien jalurnya.

Tabel 11 pengaruh disiplin kerja dan kepuasan kerja terhadap kinerja pegawai

\begin{tabular}{|l|r|r|r|r|r|}
\hline & \multicolumn{2}{|c|}{$\begin{array}{c}\text { Unstandardized } \\
\text { Coefficients }\end{array}$} & $\begin{array}{c}\text { Standardize } \\
\mathrm{d} \\
\text { Coefficients }\end{array}$ & & \\
\cline { 2 - 5 } Model & \multicolumn{1}{|c|}{ B } & \multicolumn{1}{c|}{$\begin{array}{c}\text { Std. } \\
\text { Error }\end{array}$} & \multicolumn{1}{|c|}{ Beta } & \multicolumn{1}{c|}{$\mathrm{t}$} & \multicolumn{1}{c|}{ Sig. } \\
\hline $1 \quad$ (Constant) & 3.260 & 2.810 & & 2.248 & .317 \\
Disiplin Kerja & .310 & .129 & .752 & 8.231 & .000 \\
Kepuasan Kerja & .345 & .213 & .296 & 3.171 & .035 \\
\hline
\end{tabular}

a. Dependent Variable: Kinerja

Pegawai

Sumber Data : data olahan SPSS, 2018

Pada tabel diatas dapat diketahui persamaan regresi sebagai berikut :

$Y=0,752 X_{1}+0,296 X_{2}$

Keterangan :

$$
\begin{aligned}
& Y=\text { Kinerja Pegawai } \\
& X_{1}=\text { Disiplin Kerja } \\
& X_{2}=\text { Kepuasan Kerja }
\end{aligned}
$$

Berdasarkan persamaan tersebut dapat diketahui hasil hipotesis :

Hasil koefisien regresi disiplin kerja 0,752 dan nilai signifikan sebesar 0,000 0,05. Berdasarkan hasil pengujian dapat disimpulkan bahwa pengujian tersebut mampu 
menerima $\mathbf{H}_{1}$, sehingga dugaan adanya pengaruh antara disiplin kerja terhadap kinerja pegawai terbukti atau dapat diterima. Hasil penelitian ini sama dengan penelitian yang dilakukan oleh Heni Sidanti (2015), dan Jessica Martha Kusuma (2013) dimana hasil penelitian disiplin kerja berpengaruh yang positif dan signifikan terhadap kinerja pegawai.

Hasil koefisien regresi kepuasan kerja 0,296 dan nilai signifikan sebesar 0,035 $<0,05$. Berdasarkan hasil pengujian dapat disimpulkan bahwa pengujian tersebut mampu menerima $\mathbf{H}_{2}$, sehingga dugaan adanya pengaruh antara kepuasan kerja terhadap kinerja pegawai terbukti atau dapat diterima. Hasil penelitian ini sama dengan penelitian yang dilakukan oleh Khairiyah, dkk (2013) dan Putri, dkk (2013) yang menghasilkan kepuasan kerja berpengaruh positif dan signifikan terhadap kinerja pegawai.

\section{Tahap II Regresi Linier Berganda Dengan Moderating}

Pengujian tahap 2 ini digunakan untuk mengetahui pengaruh disiplin kerja dan kepuasan kerja terhadap kinerja pegawai dengan moderasi tambahan penghasilan pegawai. Untuk pengujiannya menggunakan Multiple Regression Analysis (MRA) dengan menambahkan perkalian antara variabel disiplin kerja dengan variabel tambahan penghasilan pegawai yang menghasilkan variable Moderat1 dan perkalian antara variabel kepuasan kerja dengan variabel tambahan penghasilan pegawai yang menghasilkan variable Moderat 2

Tabel 12 Persamaan Regresi Pengaruh tambahan penghasilan pegawai dalam Memoderasi Hubungan disiplin kerja terhadap kinerja pegawai

\section{Coefficients $^{\mathrm{a}}$}

\begin{tabular}{|c|c|c|c|c|c|c|c|}
\hline \multirow[b]{2}{*}{ Model } & \multicolumn{2}{|c|}{$\begin{array}{l}\text { Unstandardized } \\
\text { Coefficients }\end{array}$} & \multirow{2}{*}{\begin{tabular}{|c}
$\begin{array}{c}\text { Standardize } \\
\mathrm{d} \\
\text { Coefficients }\end{array}$ \\
Beta
\end{tabular}} & \multirow[b]{2}{*}{$\mathrm{t}$} & \multirow[b]{2}{*}{ Sig. } & \multicolumn{2}{|c|}{$\begin{array}{l}\text { Collinearity } \\
\text { Statistics }\end{array}$} \\
\hline & B & Std. Error & & & & $\mid \begin{array}{c}\text { Toleranc } \\
\mathrm{e}\end{array}$ & VIF \\
\hline 1 (Constant) & 11.693 & 5.146 & & 2.304 & .029 & & \\
\hline Disiplin Kerja & .361 & .151 & 1.149 & 2.235 & .016 & .522 & 6.698 \\
\hline
\end{tabular}




\begin{tabular}{|c|c|c|c|c|c|c|c|}
\hline $\begin{array}{l}\text { Tambahan } \\
\text { Penghasilan } \\
\text { Pegawai }\end{array}$ & .173 & .320 & .163 & .517 & .014 & .932 & 3.491 \\
\hline $\begin{array}{l}\text { Interaksi DK } \\
\text { dengan TPP }\end{array}$ & .051 & .033 & .882 & 2.342 & .034 & .832 & 1.903 \\
\hline
\end{tabular}

a. Dependent Variable: Kinerja

Pegawai

Sumber Data : data olahan SPSS, 2018

Pada tabel diatas dapat diketahui persamaan regresi sebagai berikut :

$$
\mathrm{Y}=1,149 \mathrm{X}_{1}+0,163 \mathrm{M} \cdot 0,082 \mathrm{X}_{1}
$$

Keterangan :

$$
\begin{aligned}
& \mathrm{Y}=\text { Kinerja Pegawai } \\
& \mathrm{X}_{1}=\text { Disiplin Kerja } \\
& \mathrm{M}=\mathrm{TPP}
\end{aligned}
$$

Berdasarkan persamaan tersebut dapat diketahui hasil hipotesis :

Hasil koefisien regresi interaksi disiplin kerja - tambahan penghasilan pegawai diperoleh 0,882 dan nilai signifikansi sebesar $0,034<0,05$. Penjelasan tersebut dapat diartikan bahwa tambahan penghasilan pegawai dapat sebagai variable moderating dari hubungan antara disiplin kerja terhadap kinerja pegawai, artinya bahwa tambahan penghasilan pegawai memoderasi hubungan antara disiplin kerja terhadap kinerja organisasi dengan sifat memperkuat. Hasil penelitian ini sama dengan penelitian yang dilakukan oleh Indra Lestari Sumbung, dkk (2015)

Berdasarkan hasil pengujian dapat disimpulkan bahwa pengujian tersebut menerima $\mathbf{H}_{3}$, sehingga dugaan tambahan penghasilan pegawai sebagai variabel moderating pengaruh disiplin kerja terhadap kinerja pegawai terbukti atau dapat diterima. 
Tabel 13 Persamaan Regresi Pengaruh tambahan penghasilan pegawai dalam

Memoderasi Hubungan kepuasan kerja terhadap kinerja pegawai

\section{Coefficients $^{\mathrm{a}}$}

\begin{tabular}{|c|c|c|c|c|c|c|c|}
\hline \multirow[b]{2}{*}{ Model } & \multicolumn{2}{|c|}{$\begin{array}{l}\text { Unstandardized } \\
\text { Coefficients }\end{array}$} & \multirow{2}{*}{\begin{tabular}{|c|}
$\begin{array}{c}\text { Standardize } \\
\mathrm{d} \\
\text { Coefficients }\end{array}$ \\
Beta
\end{tabular}} & \multirow[b]{2}{*}{$\mathrm{t}$} & \multirow[b]{2}{*}{ Sig. } & \multicolumn{2}{|c|}{$\begin{array}{c}\text { Collinearity } \\
\text { Statistics }\end{array}$} \\
\hline & B & Std. Error & & & & $\begin{array}{c}\text { Toleranc } \\
\mathrm{e}\end{array}$ & VIF \\
\hline 1 (Constant) & 10.694 & 6.314 & & 2.313 & .027 & & \\
\hline Kepuasan Kerja & .765 & .335 & .702 & 2.411 & .031 & .727 & 3.140 \\
\hline Tambahan & & & & & & & \\
\hline Penghasilan & .179 & .401 & .172 & .511 & .024 & .915 & 4.402 \\
\hline Pegawai & & & & & & & \\
\hline $\begin{array}{l}\text { Interaksi KK } \\
\text { dengan TPP }\end{array}$ & .047 & .026 & .871 & 2.147 & .041 & .812 & 1.815 \\
\hline
\end{tabular}

a. Dependent Variable: Kinerja

Pegawai

Sumber Data : data olahan SPSS, 2018

Pada tabel diatas dapat diketahui persamaan regresi sebagai berikut :

$$
\mathrm{Y}=0,702 \mathrm{X} 2+0,172 \mathrm{M} \cdot 0,871 \mathrm{X} 2
$$

Keterangan :

$$
\begin{aligned}
& \mathrm{Y}=\text { Kinerja Pegawai } \\
& \mathrm{X}_{2}=\text { Kepuasan Kerja } \\
& \mathrm{M}=\mathrm{TPP}
\end{aligned}
$$

Hasil koefisien regresi kepuasan kerja - tambahan penghasilan pegawai diperoleh 0,871 dan nilai signifikansi sebesar 0,041 < 0,05. Penjelasan tersebut dapat diartikan bahwa tambahan penghasilan pegawai dapat sebagai variable moderating dari hubungan antara kepuasan kerja terhadap kinerja pegawai, artinya bahwa tambahan penghasilan pegawai memoderasi hubungan antara kepuasan kerja terhadap kinerja pegawai dengan sifat memperkuat. 
Berdasarkan hasil pengujian dapat disimpulkan bahwa pengujian tersebut menerima $\mathbf{H}_{4}$, sehingga dugaan tambahan penghasilan pegawai sebagai variable moderating pengaruh kepuasan kerja terhadap kinerja pegawai terbukti atau dapat diterima. Hasil penelitian ini sama dengan penelitian yang dilakukan oleh Yunita Sari dan M. Al Musadieq (2017)

\section{Analisis Koefisien Determinasi}

Analisis koefisien determinasi digunakan untuk mengukur seberapa jauh kemampuan model dalam menerangkan variasi variabel dependen, dimana ditunjukkan dengan nilai Adjusted $R$ Square. Berikut hasil pengujian yang dibantu dengan program SPSS sebagai berikut :

1. Pengaruh disiplin kerja dan kepuasan terhadap kinerja pegawai

Tabel 14.Koefisien determinasi pengaruh disiplin kerja dan kepuasan terhadap kinerja pegawai

\begin{tabular}{|l|r|r|r|r|}
\hline Model & \multicolumn{1}{|c|}{$\mathrm{R}$} & R Square & \multicolumn{1}{|c|}{$\begin{array}{c}\text { Adjusted R } \\
\text { Square }\end{array}$} & $\begin{array}{c}\text { Std. Error of } \\
\text { the Estimate }\end{array}$ \\
\hline 1 & $.727^{\mathrm{a}}$ & .528 & .513 & 1.767 \\
\hline
\end{tabular}

b. Dependent Variable: Kinerja Pegawai

Sumber Data : data olahan SPSS, 2018

Berdasarkan tampilan output pada tabel di atas menunjukkan bahwa besarnya prosentase variabel kinerja pegawai mampu dijelaskan oleh variabel disiplin kerja dan kepuasan kerja ditunjukkan dengan nilai Adjusted $R$ Square $\left(\mathrm{R}^{2}\right)$ yaitu sebesar 0,513. Dalam hal ini dapat diartikan bahwa kinerja pegawai mampu dijelaskan oleh variabel disiplin kerja dan kepuasan kerja dengan nilai sebesar 51,3 \% sedangkan sisanya sebesar 48,7 \% dari $(100 \%-51,3 \%)$ dijelaskan oleh variabel lain yang tidak diteliti dalam penelitian ini.

2. Pengaruh disiplin kerja dan kepuasan kerja terhadap kinerja pegawai dengan moderasi tambahan penghasilan pegawai 
Tabel 15 Koefisien determinasi pengaruh disiplin kerja dan kepuasan kerja terhadap kinerja pegawai dengan moderasi tambahan penghasilan pegawai

\begin{tabular}{|l|r|r|r|r|}
\hline Model & \multicolumn{1}{|c|}{$\mathrm{R}$} & R Square & \multicolumn{1}{c|}{$\begin{array}{c}\text { Adjusted R } \\
\text { Square }\end{array}$} & $\begin{array}{c}\text { Std. Error of } \\
\text { the Estimate }\end{array}$ \\
\hline 1 & $.922^{\mathrm{a}}$ & .849 & .837 & 1.025 \\
\hline
\end{tabular}

b. Dependent Variable: Kinerja Pegwai

Sumber: data olahan SPSS, 2018

Berdasarkan tabel di atas menunjukkan bahwa besarnya prosentase variabel kinerja pegawai mampu dijelaskan oleh variabel disiplin kerja dan kepuasan kerja yang diperkuat / dimoderat oleh variabel tambahan penghasilan pegwai ditunjukkan dengan nilai Adjusted $R$ Square $\left(\mathrm{R}^{2}\right)$ yaitu sebesar 0,837 Dalam hal ini dapat diartikan bahwa kinerja pegawai mampu dijelaskan oleh variabel disiplin kerja dan kepuasan kerja yang diperkuat / dimoderat oleh tambahan penghasilan pegawai dengan nilai sebesar $83,7 \%$, sedangkan sisanya sebesar $16,3 \%$ dari $(100 \%-83,7 \%)$ dijelaskan oleh variabel lain yang tidak diteliti dalam penelitian ini.

\section{Uji Model (uji F)}

Uji model (uji F) digunakan untuk menunjukkan kelayakan model persamaan regresi.

1. Pengaruh disiplin kerja terhadap kinerja pegawai dengan moderasi tambahan penghasilan pegawai

Tabel 16 Hasil Pengujian Model (Uji F) Persamaan II

Pengaruh disiplin kerja terhadap kinerja pegawai dengan moderasi tambahan penghasilan pegawai

ANOVA $^{b}$

\begin{tabular}{|rr|r|r|r|r|r|}
\hline \multicolumn{1}{|l|}{ Model } & Sum of Squares & Df & Mean Square & F & \multicolumn{1}{|l|}{ Sig. } \\
\hline 1 & Regression & 447.234 & 3 & 71.443 & 68.214 & $.000^{\mathrm{a}}$ \\
& Residual & 72.914 & 122 & 2.038 & & \\
\hline
\end{tabular}




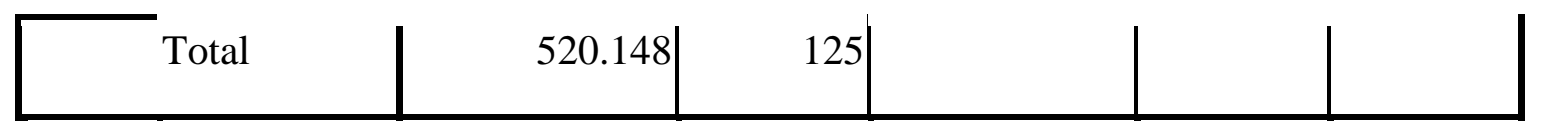

a. Predictors: (Constant), Interaksi disiplin kerja dengan Tambahan Penghasilan Pegawai,

Disiplin Kerja , Tambahan Penghasilan Pegawai, Interaksi DK dengan TPP

b. Dependent Variable: Kinerja Pegawai

Sumber Data : Data primer yang diolah, 2018

Berdasarkan tabel di atas hasil pengujian model (Uji F) pengaruh disiplin kerja terhadap kinerja pegawai dengan moderasi tambahan penghasilan pegawai dapat diketahui hasil $\mathrm{F}$ hitung 68,214 dan tingkat signifikan $0,000<0,05$ sehingga dapat dikatakan bahwa ada pengaruh antara disiplin kerja terhadap kinerja pegawai dengan moderasi tambahan penghasilan pegawai dan regresi tersebut layak digunakan dalam penelitian.

2. Pengaruh kepuasan kerja terhadap kinerja pegawai dengan moderasi tambahan penghasilan pegawai

\section{Tabel 17 Hasil Pengujian Model (Uji F) Persamaan III}

Pengaruh kepuasa kerja terhadap kinerja pegawai dengan moderasi tambahan penghasilan pegawai

ANOVA ${ }^{b}$

\begin{tabular}{|rr|r|r|r|r|r|}
\hline \multicolumn{1}{|l|}{ Model } & Sum of Squares & Df & Mean Square & F & Sig. \\
\hline $1 \quad$ Regression & 443.524 & 3 & 70.445 & 66.326 & $.000^{\mathrm{a}}$ \\
& Residual & 70.086 & 124 & 2.049 & & \\
& & 513.610 & 127 & & & \\
\hline & & & & & \\
\hline
\end{tabular}

a. Predictors: (Constant), Interaksi disiplin kerja dengan Tambahan Penghasilan Pegawai, Disiplin Kerja , Tambahan Penghasilan Pegawai, Interaksi DK dengan TPP

b. Dependent Variable: Kinerja Pegawai

Sumber Data : Data primer yang diolah, 2018

Berdasarkan tabel di atas hasil pengujian model (Uji F) pengaruh kepuasan kerja terhadap kinerja pegawai dengan moderasi tambahan penghasilan pegawai dapat diketahui hasil $\mathrm{F}$ hitung 63,326 dan tingkat signifikan $0,000<0,05$ sehingga dapat dikatakan bahwa ada pengaruh antara 
disiplin kerja dan kepuasan kerja terhadap kinerja pegawai dengan moderasi tambahan penghasilan pegawai dan regresi tersebut layak digunakan dalam penelitian.

\section{PENUTUP}

Hasil penelitian dapat disimpulkan : (1) adanya pengaruh antara Dissiplin Kerja terhadap Kinerja Pegawai sehingga hipotesis pertama dugaan terbukti atau dapat diterima; (2) adanya pengaruh antara Kepuasan Kerja terhadap Kinerja Pegawai isehingga hipotesis kedua terbukti atau dapat diterima; (3) Tambahan Penghasilan Pegawai sebagai variabel moderating pengaruh Disiplin kerja terhadap Kinerja Pegawai sehingga hipotesis ketiga terbukti atau dapat diterima; dan (4) Tambahan Penghasilan Pegawai sebagai variabel moderating pengaruh Kepuasan Kerja terhadap Kinerja Pegawai sehingga hipotesis keempat terbukti atau dapat diterima.

Implikasi kebijakan antara lain : (1) Kinerja pegawai dapat ditingkatkan melalui disiplin kerja dan kepuasan kerja yang tinggi; (2) Tambahan Penghasilan Pegawai sebagai variabel moderating dapat ditingkatkan melalui disiplin kerja dan kepuasan kerja yang tinggi. (3) Bagi PNS, hasil penelitian ini dapat digunakan sebagai masukan dalam menjalankan tugas untuk kedisipilinan dan meningkatkan kepuasan dengan adanya tambahan penghasilan pegawai.

Penelitian ini hanya terbatas pegawai dilingkungan kecamatan Banyumanik sehingga hasilnya belum bisa digeneralisasi untuk seluruh kalangan PNS di Kota Semarang. Berdasarkan keterbatasan penelitian tesebut, untuk penelitian mendatang dengan tema yang serupa dapat dilakukan dengan menambahkan sampel dan variabel lain yang dapat mempengaruhi kinerja pegawai,

Banyak faktor lainnya yang dapat mempengaruhi tingkat Kinerja Pegawai, yang dimungkinkan akan lebih relevan dan dapat mempengaruhi tingkat Kinerja Pegawai, diantaranya seperti : lingkungan kerja, program - program pelatihan bagi pegawai, dan lain - lain. Adanya keterbatasan ruang lingkup penelitian, maka untuk penelitian yang akan datang dapat dilakukan penelitian pada Kecamatan yang lain, agar dapat diketahui konsistensi teori yang telah ada sehingga dapat dikembangkan teori - teori lain dalam meningkatkan tingkat Kinerja Pegawai pada umumnya. 


\section{DAFTAR PUSTAKA}

Aimah, Siti, 2015, Analisa Pemberian Insentif Terhadap Kepuasan Kerja Karyawan Karyawan Batik Virdes Tollection Kampo Banywwangi, Jurnal Hukum Islam, Ekonomis dan Bisnis Volume 1 Nomor 1 Januari 2015, ISSN 24600083.

Anthony, Robert N dan Vijay Govindarajan. 2007. Sistem Pengendalian Manajemen. Edisi ke 11. Buku 1. Jakarta. Salemba Empat

Ermawaty, Dinny Ardian, 2015, Analisis Pengaruh pemberian Insentif Dan Lingkungan Kerja Non Fisik Terhadap Kepuasan Kerja Serta Dampaknya Terhadap Kinerja Karyawan, Study, pada PT. PLN. Distribusi Jateng dan DIY.

Ghozali, Imam, 2011, Aplikasi Analisis Multivariate Dengan Program, IBM SPSS 19, Edisi Revisi, Badan Penebit Universitas Diponegoro, Semarang.

Hasibuan, Malayu S.P, 2007, Manajemen Sumber Daya Manusia, Edisi Revisi, Bumi Aksara.

Indra Lestari Sumbung, Syaikhul Falah, Alfiana Antoh. 2015. Pengaruh Motivasi dan Disiplin Terhadap Kinerja Pegawai Dengan Pemberian Insentif Sebagai Variabel Moderasi (Studi Kasus Di Sekretariat Daerah Kabupaten Jayawijaya). Jurnal Keuda Vol. 2 No. 1. ISSN 2477-7838

Juwita, Ice Ratna dan Astuti, Indah Yuni, 2013, Pengaruh Pemberian Insentif Terhadap Kinerja Karyawan Medis dan Paramedis di RSUD Gambiran Kediri, Jurnal Cendekia Volume 11 Nomor 2 Mei 2013.

Khairiyah dan Annisa, Nur Syaima, 2013, Pengaruh Kepuasan Kerja, Gaya Kepemimpinan, Dan Motivasi Kerja Terhadap Kinerja Karyawan Pada PT. Nutricia Indonesia Sejahtera, Proceeding PESAT Bandung Volume 5 Oktober 2013 ISSN : 1858-2559.

Kurniasih, Sri Anita Sutresna, 2013, Pengaruh Etos Kerja Dan Disiplin Kerja Terhadap Kinerja Pegawai, Study pada Aparat Pemerintahan Kecamtan Baregbeg Kabupaten Ciamis.

Kusuma, Jesssica Martha, 2013, Pengaruh Insentif, Motivasi Kerja Dan Disiplin Kerja Terhadap Kinerja Karyawan, Study Kasus Pada Karyawan Bagian Produksi PT. Sido Muncul Semarang, Dinamika Manajemen Volume 2 Nomor 6 Februari 2013.

Mangkunegara, A.A. Anwar Prabu, 2013 Manajemen Sumber Daya Manusia Perusahaan, Remaja Rosdakarya, Bandung.

Manoppo, Rivo, 2015, Pengaruh Disiplin Kerja, Motivasi Kerja dan Pengembangan Karir Terhadap Kepuasan kerja Pada TVRI Sulawesi Utara, Jurnal EMBA Volume 3 Nomor 3 September 2015, Hal.1220-1231. 
Munandar, Ashar Sunyoto, 2012, Psikologi Industri dan Organisasi, Penerbit Univertas Indonesia, Jakarta.

Panggabean, Mutiara S, 2002, Manajemen Sumber Daya Manusia, Gholia Indonesia, Jakarta.

Primasani, Adil Mumpuni, 2013, Pengaruh Buday Organisasional, Locus Of Control Terhadap Kinerja Pegawai Dimediasi Kepuasan Kerja, Studi Pada Dinas Pengelolaan Keuangan Dan Aset daerah Kota Semarang.

Putri, Putu Yudha Asteria dan Latrini, Made Yenni, 2013, Pengaruh Kepuasan Kerja Terhadap Kinerja Karyawan Sektor Publik, Dengan In-Role Performance Dan Innovative Performance Sebagai Variabel Mediasi, E-Jurnal Akuntansi Universitas Udayana 5.3 (2013) : 627-638.

Rismayan. Syahrani dan Irawan, Bambang, 2013, Faktor-Faktor yang Berpengaruh Terhadap Tingkat Kepuasan Kerja PEgawai Pada Dinas Perhubungan Komunikasi Dan Informatika Kabupaten Kutai Timur, eJurnal Administrarive Reform, 2013, 1(4) : 744757.

Sadtyaji, Dewi, 2016, Pengaruh Iklim Organisasi, Pengembangan Karir Dan Keadilan Kompensasi Terhadap Kepuasan Kerja Study Pada Unit Kerja Berbentuk Badan Pada Pemerintah Kota Semarang.

Sekaran, Uma, 2015, Research Methods For Business, Buku 2, Edisi 4 Salemba Empat.

Settiawan, Agung, 2013, Pengaruh Disiplin Kerja dan Motivasi Terhadap Kinerja Karyawan Pada Rumah Sakit Umum Daerah Kanjuruhan malang, Jurnal Ilmu Manajemen Vollume 1 Nomor 4 Juli 2013.

Setyowati, Novi, Pengaruh Kedisiplinan dan Kepemimpinan Terhadap Kinerja Pegawai Negeri Sipil Melalui Kepuasan Kerja Sebagai Variabel Intervening, Sutdy Pada Balai Besar Wilayah Sungai Pemali-Juana Semarang.

Sidanti, Heny, 2015, Pengaruh Lingkungan Kerja, Dispilin Kerja Dan Motivasi Kerja Terhadap Kinerja Pegawai Negeri Sipil Di Sekretariat DPRD Kabupaten Madiun, Jurnal JIBEKA Volume 9 Nomor 1 Februari 2015 : 44-53.

Sukmasari, Hentry, 2011, Pengaruh Kepemimpinan, Motivasi, Insentif, Lingkungan Kerja Dan Kepuasan Kerja Terhadap Kinerja Pegawai Dinas Pengelolaan Keuangan Dan Aset Daerah Kota Semarang.

Sutrini, 2015, Analisis Pengaruh Karakteristik Individu, Budaya Organisasi Dan Kepemimpinan Terhadap Kinerja Pegawai Melalui Kepuasan Kerja Sebagai Variable Intervening, Study Kasus Pada Dinas Perindustrian Dan Perdagangan Provinsi Jawa Tengah. 
Sutrisno, Edy, 2012, Manajemen Sumber Daya Manusia, Kencana, Prenadamedia Group, Jakarta.

Yunita Sari dan M. Al Musadieq. 2017. Pengaruh Lingkungan dan Kepasan Kerja Terhadap Kinerja Pegawai Dengan Pemberian Insentif Sebagai Variabel Moderasi (Studi Kasus Karyawan PT Pertamina Geothermal Energy Kantor Pusat Jakarta). Jurnal Administrasi Bisnis (JAB)|Vol. 59 No.1 Juni 